\title{
Re-configuring Non-refoulement? The Suresh Decision, 'Security Relativism, and the International Human Rights Imperative
}

\author{
OBIORA CHINEDU OKAFOR* AND PIUS LEKWUWA \\ OKORONKWO**
}

We conclude that generally to deport a refugee, where there are grounds to believe that this would subject the refugee to a substantial risk of torture, would unconstitutionally violate the Charter's s.7 guarantee of life, liberty and security of the person. This said, we leave open the possibility that in an exceptional case such a deportation might be justified either in the balancing approach under $\mathrm{ss.} 7$ or 1 of the Charter. ${ }^{1}$

... we find that Suresh made a prima facie showing that he might be tortured on return if expelled to Sri Lanka. ${ }^{2}$

\section{Abstract}

This article critically analyses the decision of the Supreme Court of Canada in the Suresh case, especially with regard to its underlying basis in doctrine and policy, and its

- Associate Professor at the Osgoode Hall Law School, and Faculty Member at the Centre for Refugee Studies - York University, Toronto, Canada. Most recently a Visiting Scholar, Human Rights Program, Harvard Law School, Cambridge Massachusetts, USA. LL.B (Hons), LL.M. (University of Nigeria, Enugu Campus); LL.M, Ph.D. (University of British Columbia, Vancouver, Canada). E-mail address: ookafor@yorku.ca. The authors would like to express their deep gratitude to Karin Mickelson and Dylan Yaeger, for their persuasive and painstaking commentary on parts of earlier versions of this article. The authors are also indebted to Craig Scott, for his helpful suggestions, in oral discussions, regarding part VII of the article. The excellent research assistance of Alia Ahmed and Jean-Marie Dixon is also acknowledged. The Social Sciences and Humanities Research Council of Canada provided the generous funds (granted to Obiora Okafor) that helped make this article possible.

** Doctoral Candidate, Osgoode Hall Law School, York University, Toronto, Canada. LL.M (Dalhousie University, Halifax, Canada); LL.M (University of Lagos); LL.B (Hons) (University of Nigeria, Enugu Campus).

1 Manickavasagam Suresh $v$ Canada (Minister of Citizenship and Immigration) 2002 SCC 1.File No.: 27790 (hereafter 'Suresh') at para. 129. Emphasis supplied. The italicization of the word 'Charter' is however reproduced from the decision.

2 Ibid. at para. 130 .

International Journal of Refugee Law vol. 15 no. 1 O Oxford University Press 2003; all rights reserved 
implications for the non-refoulement norm. The principal conclusions of this article are as follows. In the first place, laudable as it mostly is, the Suresh decision is based on a number of apparently credible, although flawed, images of certain important policy and doctrinal assumptions and constructs. The decision relies on a conception of the desiderata for Canadian national security that is flawed on two scores - because its conception of security interdependence is so overly formalist as to be hardly reassuring to those in fear of terrorism and other such threats. The decision relies on an image of torture (and deportation) to torture that is relativist and pragmatic - one that sees torture as something that can be balanced away by a national security risk - one that is thus unsatisfactory from an international human rights perspective. The decision also relies on specific images of near absolute state sovereignty and weak international normative authority - images that constrained its decision in unsatisfactory ways. It also relies on a much too benign image of the Canadian immigration bureaucracy, onc that allowed it to effectively allow an unsatisfactorily very high level of hard-to-review discretion to that entity. Secondly, these flawed images worked together to lead the court to conclusions that will in practice not ensure that the vast majority of refugees and other persons at risk of torture are not deported to places where they face a substantial risk of torture. Consequently, a critical analysis of the nature of Canada's post-Suresh decision non-refoulement regime reveals that that regime still falls short of the requirements of the general norm that prohibits deportations to torture (especially in its likely practical operation).

\section{Introduction}

On January 11, 2002, the Supreme Court of Canada released four decisions concerning the legality of the attempts made by Canada to deport certain non-citizens from Canada. ${ }^{3}$ Two of those decisions concern the deportation, on national security grounds, of convention refugees to places where they would likely face a substantial risk of torture. ${ }^{4}$ The more important of these two decisions was rendered in the Suresh case. ${ }^{5}$

This last decision will have extremely important implications for Canada's protection of refugees and persons at risk, and for the ability of Canada to refoule (that is, deport to a place where they are at risk) persons who have already been accepted as convention refugees in Canada, or who otherwise remain at risk of persecution in the place to which they are deportable. It may also have some persuasive value in the courts of other refugee-receiving countries. ${ }^{6}$ In any event, this

\footnotetext{
${ }^{3}$ See Suresh, n. I above; Mansour Ahani v Canada (Minister of Citizenship and Immigration 2002 SCC 2. File No.: 27792 (hereafter 'Ahani'); Chieu $v$ Canada (Minister of Citizenship and Immigration) 2002 SCC 3. File No.: 27107; and Al Sagban v Canada (Minister of Citizenship and Immigration) 2002 SCC 4. File No.: 27111.

${ }^{4}$ See Suresh, n. 1 above and Ahani, ibid.

5 Ibid.

6 The courts of the major western refugec receiving states often cross-reference each others decisions. For instance, in Suresh, the Supreme Court of Canada was persuaded by much of the reasoning in Secretary of State for Home Department v Rehman [2001] 3 W.L.R. 877 - a decision of the British House of l.ords.
} 
decision has extremely important implications for the way convention refugees and asylum seekers are treated not just in Canada, but the world over as well, especially in our current post-9/11 world order. ${ }^{7}$ Given its importance and topicality, it is crucial that much scholarly attention be paid to this decision - not just in terms of understanding its doctrinal and other basis, but also in terms of appreciating more fully its broader implications.

Our overarching objectives in this article are two-fold. First of all, we will examine the Suresh decision closely, especially its more important aspects, with a view to understanding and articulating the various images (and thus understandings) of certain aspects of social reality and a number of specific socio-legal constructs that the decision either prefers or displaces, and to consider the various ways in which this underlying process of image preference and displacement was constitutive of the conclusions reached by the court, in the sense that it functioned to shape and produce a particular outcome, and to construct that outcome as the right answer - the only viable legal position. In particular, we will focus on the images of Canadian national security, torture, the authority of international legal norms, state sovereignty, and the workings of the Canadian Immigration bureaucracy, that are developed, preferred, and relied on in the decision, as well as on those alternative images of these same phenomena and constructs that are thereby displaced. We will attempt to expose the contingency of this underlying process of image preference and displacement by developing and articulating viable alternatives to the images that the court preferred to privilege. Here, our broad argument is that it was only by a subtle and sophisticated process that involved the largely unjustified displacement of other viable alternative images of the relevant phenomena and constructs that the court was able to construct the kind of decision that it reached eventually - a decision that, laudable as it mostly is, did not go nearly as far as it could in the direction of entrenching the expanded (anti-torture) non-refoulement norm in Canadian law; a decision that, was disappointing as a result.

This analytical exposé will form the basis for our second overarching pre-occupation in this article: i.e our attempt to articulate the nature of Canada's emergent (non-) refoulement regime (especially as it relates to already accepted convention refugees), and predict the likely outcomes,

\footnotetext{
${ }^{7}$ For an excellent commentary on the nature of the emerging global order, see U. Baxi, 'Operation "Enduring Freedom": Towards a New International Law and Order?' in A. Anghie, et al. eds., The Third World and International Order: Law, Politics and Globalization (The Hague: Kluwer Law International, forthcoming) - noting inter alia that 'the Clio's couch, the disengagement that only distance can bring, is not for us the gift of time'.
} 
in the vast majority of cases, of the practical application of the formal legal norms and rules that constitute that emergent regime. Thus, we will attempt to specify in outline the nature of the conceptual framework for, and likely practical implementation of, the emergent nonrefoulement regime in Canada - especially as it relates to deportations to torture. Here, our contention is that in concrete terms, the decision will turn out not to be critically transformative of the pre-existing (and rather unsatisfactory) Canadian non-refoulement regime. The decision will not turn out to be transformative, at least in the sense that as a result of an odd calculus of conclusions reached in the decision and the nature of the current security climate in Canada, far too many refugees could still be deported to places where they face a substantial risk of torture.

At the outset, however, it is important to acknowledge and recognize the fact that in the context of the mass public outrage that followed the terrible events that occurred in the USA on September 11, 2001, and the accompanying (and somewhat understandable) rise in the level of security related hysteria in Canada as elsewhere ${ }^{8}$ and given the earlier dismissal of Mr Suresh's appeal by the Federal Court of Appeal of Canada, the Supreme Court's decision in this case is likely to be welcomed with much relief by most refugees, refugee advocates, and refugee lawyers. The court displayed, yet again, its remarkable ability to manoeuvre quite effectively between ethical principle and popular politics, between a commitment to normative supremacy, and the understandable allure of pragmatic (security-related) relativism, while reducing to the barest minimum public censure of its decisionmaking. ${ }^{9}$ The happy practical result in the present case will most likely be some reduction in the ability of Canada's Immigration bureaucracy to deport refugees to places where they face a substantial risk of torture. That is not to say, however, that the court's reasoning is unassailable, at least from the point of view of those minded to advance the best interests of refugees. Indeed, as we will show toward the end of this paper, in concrete terms, the decision stopped far short of ensuring that the deportation of refugees and other persons at risk to torture would now be a thing of the past.

\footnotetext{
${ }^{8}$ For instance, see Transport Canada, 'Government of Canada introduces Public Safety Act' on line: http://ww.tc.gc.ca/mediaroom/releases/nat/2001/01_hl47e.htm (visited: 14/03/2002).

9 For a good example of this kind of behaviour, see Re: Reference by the Governor in Council Concerning cerlain questions relating to the Secession of Quebec from Canada (1998), 161 D.L.R. (4th series) 385 .
} 


\section{The background and nature of the decision ${ }^{10}$}

In 1991, the Convention Refugee Determination Division of the Immigration and Refugee Board of Canada recognized Mr Manickavasagam Suresh as a convention refugee. Under Canadian law, the recognition of Suresh as a convention refugee entitled him to apply for landed immigrant or permanent residence status in Canada. In the summer of that same year, Suresh made that application.

The application was in process for four years and was never finalized. This was because in late 1995, the Solicitor General of Canada (who oversees the security services) and the Minister of Citizenship and Immigration (who oversees the department of citizenship and immigration or CIC) ${ }^{11}$ issued a certificate under Section 40.1 of the then operative 1978 Immigration Act of Canada ${ }^{12}$ alleging that Suresh could not be granted permanent residence status and was inadmissible in Canada on security grounds pursuant to Section 19 of that same Act. The certificate alleged that Suresh was a high-ranking member of the Liberation Tigers of Tamil Elam (LTTE) otherwise known as the Tamil Tigers. The certificate also alleged that Suresh was a fundraiser for the LTTE and functioned in that capacity in Canada under the auspices of the World Tamil Movement. The LTTE, an organization composed of members of the Tamil minority ethnic group in Sri Lanka, was engaged in an armed struggle against the "democratically elected government' of that country. The certificate further alleged that the LTTE is a terrorist organization, and that Suresh's fundraising activities supported the activities of that group.

As required under Canadian law, this security certificate was filed in the Federal Court of Canada in order to determine its reasonableness. As a result, Suresh was arrested and detained on October 18, 1995. In 1997, Teitelbaum, J. of the Federal Court (Trial Division) upheld this certificate as reasonable. He found that Suresh was a top member of the LTTE; that the LTTE has committed terrorist acts; and that Tamils, such as Suresh, who are arrested by the Sri Lankan authorities, are sometimes subjected to torture by the security agencies.

At the deportation hearing that followed, an adjudicator found that although there were no reasonable grounds to conclude that Suresh was directly engaged in terrorism, he ought to be deported since, in the adjudicator's view, he was a member of a terrorist organization.

In early 1998, after considering the pro-deportation recommendation of an immigration officer who had also concluded that Mr Suresh

\footnotetext{
${ }^{10}$ Much (but not all) of the material included in this section is gleaned from the judgment of the Supreme Court in this case. See Suresh, $\mathbf{n}$. 1 above at paras 7-23.

11 Hereinafter referred to as 'the Minister'.

12 See Immigration Act 1976-77, c.52, s.1 (Hereinafter referred to as 'the old Act').
} 
faced a risk of torture upon return to Sri Lanka, the Minister issued an opinion under section 53(1)(b) of the old Act declaring that Suresh constituted a danger to the security of Canada, and ordering his deportation. The officer had considered Suresh's submissions before making the recommendation. However, prior to the Minister's decision, Suresh had not been provided with a copy of the officer's memorandum to the Minister nor was he given an opportunity to respond to the officer's conclusion.

Section 53(1)(b) of the old Act (and Section 115(2) (a) (b) of the current Immigration and Refugee Protection Act of $2001^{13}$ ) had permitted the Minister to order the deportation of a convention refugee who an adjudicator had found to be a member of a terrorist organization; against whom a Section 40.1 (national security risk) certificate had been issued and found reasonable by a judge of the Federal Court, and against whom the Minister had issued an opinion declaring her or him to be a danger to the security of Canada. ${ }^{14}$

Thus, at this point, Suresh would have been deported to Sri Lanka forthwith had he not applied immediately to the Federal Court for judicial review of the deportation order that had been made against him. ${ }^{15}$ Suresh alleged that the Minister's decision was unreasonable; that the relevant deportation procedures under the old Act were unfair; and that, inter alia, the old Act was unconstitutional, in the sense that it violated Section 7 of the Canadian Charter of Rights and Freedoms. ${ }^{16}$ McKeown, J. acknowledged Suresh's argument that the analysis of the requirements of fundamental justice under Section 7 must be informed by international law, especially the Convention Against Torture $^{17}$ (which prohibits in absolute terms the deportation of any person to a place where s/he faced a substantial risk of torture). However, the court concluded that (a) Suresh had not shown that he faced a substantial risk of torture if deported to Sri Lanka; and (b) given the risk posed to Canadian national security by Suresh, his deportation to a place where he is likely to be tortured would not 'shock the conscience' of Canadians. The court therefore dismissed Suresh's application for judicial review.

13 See the Immigration and Refugee Protection Act, S.C. 2001, c.27 (hereinafter the 'new Act').

${ }^{14} \mathrm{~S} .53(\mathrm{l})(\mathrm{b})$ of the old act provides that: ' . . the person is a member of an inadmissible class described in para. $19(\mathrm{l})(\mathrm{e}),(\mathrm{f}),(\mathrm{g}),(\mathrm{j}),(\mathrm{k})$, or (l) and the minister is of the opinion that the person constitutes a danger to the security of Canada'.

${ }_{15}$ Suresh Re (1997), 40 Immigration Law Reports (2d) 247 at 260-262.

16 Canadian Charter of Rights and Freedoms on line: http://www.efc.ca/pages/law/charter/charter. text.html\#34 (hereinafter 'the Charter').

17 Convention against Toriure and other Cruel, Inhuman or Degrading Treatment or Punishment of 10 December 1984 reprinted in Collection of International Instruments and Other Legal Texts Concerning Refugees and Displaced Persons Vol.1, Universal Instruments (Geneva: UNHCR, 1995) 233, article 3 (hereinafter 'the Torture Convention'). 
Suresh's appeal to the Federal Court of Appeal of Canada was similarly dismissed. ${ }^{18}$ Robertson J.A., for the court, held that: (a) Canada's sovereign right to expel those who pose a security risk limits the international legal right to be free from torture; (b) the Convention Relating to the Status of Refugees permitted derogation from the prohibition against deportation to torture; (c) S.53 (1)(b) of the old Act was not unconstitutional even though it permitted deportations to torture; (d) while deportations to torture violated Section 7 of the Charter, such deportations were saved by Section 1 of the same document (which permits reasonable and proportional derogations in the interest of Canadian national security); (e) the expulsion to torture of a person that posed a danger to Canadian national security would not violate the sense of justice or shock the conscience of most Canadians because Canada would have acted merely as an involuntary intermediary; and ( $f$ ) the administrative decision-making process under Section $53(1)$ (b) conformed with Section 7 of the Charter.

It was from this decision that Suresh appealed to the Supreme Court of Canada. The court allowed the appeal, overturned the decision of the Federal Court of Appeal below, and ordered that a new deportation hearing before an adjudicator (which must be guided by the court's reasoning and decision) be convened in respect of Suresh's matter. For our present purposes, the court found, inter alia, that:

(a) According to both Canadian and international law, deportations to torture will, in general, violate the principles of fundamental justice as enshrined in Section 7 of the Charter - though in exceptional circumstances deportations to torture could be justified 'either as a consequence of the balancing process mandated by s. 7 of the Charter or under s. $1 ., 19$

(b) The Convention against Torture absolutely prohibits deportations or expulsions to torture, and this international law prohibition is at least 'not easily derogable', and at most a peremptory norm of general international law. ${ }^{20}$ Moreover, the provisions of the Refugee Conven$t i o n^{21}$ and the International Covenant on Civil and Political Rights ${ }^{22}$ (which are not as absolute and explicit in their prohibition of deportations to torture) cannot be used to deny rights to convention refugees that other legal instruments confer universally on everyone. ${ }^{23}$

18 Suresh v. Canada (Minister of Citizenship and Immigration) [2000] 2 F.C. 592 (C.A.).

19 See Suresh, n. 1 above at para. 78.

20 Ibid. at paras $61-66$, especially at 66 .

21 Convention Relating to the Status of Refugees, 28 July 1951, 189 UNTS 137, came into force 22 April 1954 (hereinafter 1951) Arts 32(2) \& 33(2).

22 International Covenant on Civil and Political Rights (1966) 999 UNTS 171, UN Doc. A/6316 (1966) (entered into force March 23, 1976) Art. 7.

${ }^{23}$ See para. 72. 
(c) International treaty norms (including international human rights norms) are not, strictly speaking, either binding on Canadian courts or directly applicable within the Canadian legal order, unless they have been incorporated into Canadian law by enactment. ${ }^{24}$

(d) In permitting deportations in some exceptional cases to a place where a convention refugee may face torture, Section $53(1)$ (b) does not therefore necessarily violate Section 7 of the Charter. The Minister is obliged to apply it in ways that do not violate the Constitution.

(e) The procedures under Section $53(1)$ (b) are not fair because they do not give the prospective deportee an opportunity to know and meet the case against her or him in circumstances where s/he had made out a prima facie case of a substantial risk of torture.

(f) The standard of review by the courts of the Minister's decision to deport a convention refugee is intended by the Act to be a highly deferential one. Even if the court would have itself reached a different conclusion, the courts are not to interfere with the Minister's decision unless it is patently unreasonable (the most deferential standard available).

In the subsequent sections of this article, we will closely examine a number of these conclusions with a view to understanding the logic that underlie and structure them. Thereafter, we will attempt to flesh out the implications of these conclusions for the formal rules and concrete application of Canada's emergent non-refoulement regime.

\section{The images of Canadian national security in the decision}

In this section, we will attempt to tease out and analyse two complementary images of the desiderata for Canadian national security that are developed in the Suresh decision, and show how these images worked to displace alternative, and perhaps even more realistic, images of the same phenomenon. Here, our primary objective is to articulate the ways in which the images that were preferred by the court constrained its overall legal reasoning and conclusions in ways that are, on the balance, unsatisfactory.

The first image of the desiderata for Canadian national security that is developed, preferred, and relied on by the court is that of security

24 Suresh n. 1 above at para. 60. 
interdependence. Quite understandably, the court was of the firm view that 'the security of one country is often dependent on the security of other nations'. ${ }^{25}$ It was convinced, and rightly so in our view, that events that occur elsewhere may still have a negative effect on Canadian national security; that the global transport and money networks that feed terrorism or other such security threats have the potential to touch all countries, and that international cooperation is essential in effectively combating terrorism. ${ }^{26}$ However, the court also recognized that not all threats to the security of another country would pose a threat to Canada's security. In its view, though the threat to Canada's security need not always be a direct one, in the envisaged cases of indirect threats, 'there must be a real and serious possibility of adverse effect to Canada' ${ }^{27}$ In the end though, the image of Canadian national security that the court constructed in this portion of its judgment relied too much on an image of the likely human sources of such threats as indiscriminate purveyors of terrorist violence, who can attack or otherwise harm any country whatsoever at any time, necessitating the need for a country such as Canada to act individually or in common against any person or group that attacks or is likely to attack any other country, lest Canada itself become the next target. While this view seems reasonable, and is certainly ingrained quite deeply in the conventional understanding of the events of September 11, $2001-$ events that the court itself relied on in order to construct this image ${ }^{28}-$ it is not an altogether unassailable understanding of those events and their context. As understandable and reasonable as this broad view of the sources of threats to Canadian national security is, it displaces, albeit subtly, a much more holistic image of the behaviour of the likely sources of such threats. It displaces an image of such threats as much more discriminate than indiscriminate. It tends to occlude history, context, and reality. In reality, unfortunate as it is, virtually every one of the likely sources of the anticipated threats to Canadian national security have historically displayed a tendency to select their targets carefully and with much discrimination - based on sometimes real and sometimes imagined (but almost always predictable) historic grievances. For instance, it will be very difficult to prove 'a real and serious possibility of adverse effect on Canada' of the armed activities of the LTTE, entirely conducted as they are, within Sri Lanka. The LTTE's sole purpose, as the court itself acknowledged, is to redress what it vieves as Sri Lanka's repression of its Tamil minority. ${ }^{29}$ In fact, the bulk of the other evidence

$\begin{array}{ll}25 & \text { Ibid. at para. } 90 . \\ 26 & \text { Ibid. at para. } 88 . \\ 27 & \text { Ibid. } \\ 28 & \text { Ibid. at para. } 87 . \\ 29 & \text { Ibid. at para. } 10 .\end{array}$ 
suggests that such targets have much more often than not been selected with real or imagined grievances in mind. ${ }^{30}$ It may of course be argued in reply that even a highly discriminate strategy on the part of a group that is viewed as terrorist may still result in an act of terrorism being perpetrated on Canadian soil even when Canadians are not the targeted group, thereby triggering national security concerns. An example of such a situation would be if a group such as the LTTE plans to bomb or bombs the Sri Lankan High Commission in Canada. The example of the bombing of the USA's Embassy in Nairobi, Kenya, and the bombing of the Air India jet that killed Canadians, may be offered to illustrate this point. It is conceded that the enactment of such a disturbing scenario is, unfortunately, a possibility. In addition, a foreign embassy or other entity (that is sited in Canada) may be targeted by terrorists, thus implicating Canadian national security concerns. Our argument, however, is that given the relevant historical evidence it is rare that such struggles are directed at Canada - indeed such groups usually want to enlist Canada as an ally because of its comparatively more benign image internationally. As such, while such bombings may occur, the chances are relatively remote. The point is that there is no necessary linkage between the conduct of terrorist activities in a foreign country and the generation of a real risk to Canadian national security. And so the mere fact that a group is a terrorist group does not automatically mean that Canada's national security necessitates the expulsion of its members from Canada. This may well be so in some cases, but the linkage has to be demonstrated carefully.

Moreover, the image of the desiderata for security interdependence advanced by the court was an overly formalist, as opposed to a substantive, one. The court did not seem to give much thought to the alternative view that Canada's security may be much more dependent on a just, and therefore durable, resolution of certain civil conflicts abroad, and that such a durable solution will be unlikely if, by deporting top members of the armed opposition to the same country that these rebels fled in fear of persecution, Canada will have effectively intervened in that civil conflict on the side of the status quo, on the side of the very governments that Canada itself has often viewed as guilty of atrocities against the rebellious population. However, while a careful consideration of the reality of our current global circumstance will tend to weaken severely the specific notion we must add that security interdependence that was relied on so heavily by the court, it does not completely negate it. What is being urged here though is that the court

\footnotetext{
${ }^{30} \mathrm{Few}$, if any, of the activities around the world that are normally viewed as terrorist have been indiscriminate in nature. From the Middle East to Chechnya, from Indonesia to Spain, from Northern Ireland to the Philippines, such activities have been limited scope and definitcly targeted-oriented in nature.
} 
relied on an image of security interdependence that was far too decontextualized - a level of reliance that helped significantly to shape its decision to allow the Minister the authority to order, in exceptional cases, the deportation to torture of a refugee or other person at risk; a decision that as we shall soon show is, on balance, unsatisfactory.

Had the court not felt able to rely so heavily on the de-contextualized image of Canadian national security we have articulated already, it may not have been able to find that Suresh's activities in Canada were of the kind that could likely pose a proximate danger to the security of Canada. And even if it still felt that his activities did pose a danger to Canada's national security, the court may have been more inclined to view any such potential danger to Canada with less alarm. Again, if the court had found that Suresh's fundraising activities, entirely directed as they were against Sri Lanka, did not fit within the meaning of the phrase 'danger to the security of Canada', then Suresh would not have been removable from Canada in the first place, regardless of the answer to the question of Canada's ability to deport a refugee or other person at risk to torture. This is because he would not have fitted within the class of refugees contemplated by Section 53(1)(b) of the old Act. As such, by viewing the likely sources of the anticipated threats to Canada's security in the formalistic way it did, and not in the alternative way already canvassed, the court itself constrained its own decision in a rather unsatisfactory direction. This was a very significant, albeit subtle, argumentative move on the part of the court given the fact that at least two expert refugee law scholars have suggested that the travaux préparatoires of the Refugee Convention indicate that threats to the security of another country do not qualify as a threat to the security of the asylum state sufficient to allow that state to deport a convention refugee to torture. ${ }^{31}$

The second image of the desiderata for Canadian national security that was relied on as heavily by the court is the notion that a 'fortress Canada' that is secure and terrorist-proof largely because of what Canada does or does not do with its immigration/refugee law and policy is even possible in the first place. While it was reasonable for the court to suppose, as most people do, that it is a legitimate objective of immigration/refugee policy to attempt to do what it can to help secure the country from those who would harm its residents, the court looked far too kindly upon the idea that constructing a 'fortress Canada' that is virtually impenetrable to security threats is either practicable or a durable way of ensuring Canada's national security. In our view, the court relied too heavily on an alluring but somewhat unrealistic image of the possibility

\footnotetext{
31 See J.C. Hathaway and C.J. Harvey, 'Framing Refugee Protection in The New World Disorder' (2001) 34 Comell Int'l L. J. 257 at 289-290.
} 
of constructing, largely via Canadian immigration/refugee law, policy and action, a serene, safe fortress Canada devoid of terrorist or other kinds of security threats. The court's reliance on the idea that Canada's national security can be assured largely by keeping out terrorists or other security threats is evident from its repeated reference in the decision to Canada's 'legitimate and compelling interest in combating terrorism', and to 'preventing Canada from becoming a safe haven for terrorists' as an imperative that might justify deportations to torture in exceptional cases, an action that would otherwise be impermissible. The discerning reader is left with the impression that the court is convinced that ifCanada does not retain this power to deport refugees to torture, albeit in exceptional cases, then Canada's national security will of necessity be adversely affected. Given the court's strongly expressed aversion in general to the deportation of refugees and other persons to torture, it is only by reading the court as viewing such deportations as sometimes absolutely essential to the worthy project of keeping Canada free from terrorism, that their willingness to permit them in some cases can make sense.

However, no explicit or implied mention is made in the judgment of a range of alternative third ways that lie between deporting refugees and other persons at risk of torture, and leaving them completely free in Canada. Yet it is not that difficult to imagine a number of viable and credible third way alternatives between those two poles. For instance, in those cases where evidence of a crime is available, rather than deport them to torture these persons could be tried, convicted, and imprisoned as other serious criminals are. The possible reasonable objection to our argument that these third ways should have guided the court toward upholding international law's absolute bar on deportations to torture is that the law can and should never speak in absolutes; that since the law cannot possibly see into the future, it should not place an absolute bar on deportation to torture. In this sense, it is urged that in future there may arise a case in which a deportation to torture was the only way to save millions of Canadian lives. While persuasive at first glance, such an argument is hardly convincing. Two responses may be offered in reply. In the first place, Canadian law already speaks in absolutes in relation to the deportation of a terrorist who is a Canadian citizen! For instance, if a child were to be born in Canada of parents from a foreign country who are students in Canada, and his parents then take him back to that foreign country after their studies when he is six months old, if he grows up to become a terrorist and comes to Canada to live when he is forty years old, it is impossible under Canadian law to deport him at all, even more to deport him to torture. Consider that this same person has a sister who was not born here, and as such is not a Canadian citizen, but who comes to Canada to live with him. The Suresh decision will, in some cases, allow this other person to be deported to torture even when 
the risk she poses to Canadian national security may not be as serious as that posed by her sibling who is a Canadian citizen. Thus, in this case, the formality of her citizenship and not the seriousness of the risk that she poses to Canada's national security is the determining factor as to her deportation to torture. This is a form of formalism that bears very little or no relationship to the desiderata for securing Canada from terrorism. There is no ethical or substantive basis for deporting the one to torture and not the other - save of course for their different citizenships! Secondly, the law already speaks in absolutes with regard to certain kinds of serious human rights violations such as genocide. Genocide is now absolutely barred under international and Canadian law. Would the court have so easily allowed a window for the state to deport a person to genocide, even in exceptional cases? As such, the argument that the law can and should never speak in absolutes is unconvincing as a justification for allowing the deportation of refugees and persons at risk of torture. Yet, the credible alternatives to this kind of unhelpful formalism (that cannot assure the security of Canadians) are completely displaced in the court's judgment by their heavy reliance on this rather unrealistic notion of the possibility of a completely terrorist-free fortress Canada (that could be largely constructed by Canadian refugee law, policy and action). Try as it may, it will become increasingly difficult for Canada, or any other country, to prevent an undesired, yet determined, group from arriving and taking up residence within its territory.

Displaced as well, from the court's logic, is the alternative image of Canadian national security as dependent on the achievement of a more durable and effective solution to Canada's national security concerns via Canada's work abroad, as opposed to its actions within its territory. Canada could do much more than it previously has in helping to find more just, and therefore more durable, resolutions to the extreme poverty, frustrating grievances, and violent conflicts that engender the kinds of threats to national security by which Canada is quite understandably concerned. These efforts are much more likely to lead to more durable solutions to these concerns than any manner of immigration law, policy or action, no matter how draconian or thorough.

Thus, in the broader scheme of things, and given the alternatives, it does not seem to be right to imagine, as the court did, that preventing all deportations to torture would in itself be likely to have a significantly adverse impact on the national security of Canada or any other state for that matter. Yet the court's decision to leave the door open, however slightly, for Canada to be able to deport refugees and other persons at risk to torture, is largely founded on the opposite assumption, on the contrary image of Canadian national security - that is, that to deprive the Minister of the ability to deport persons at risk to torture will, in such exceptional cases, necessarily pose a significant threat to the security 
of Canadians. The court's heavy reliance on this contrary image, and the high level of implied credence it gave to the fortress construction image of a viable Canadian security policy, inevitably constrained its legal reasoning and helped in this way to shape its primary conclusion in the decision. If the court had favoured the alternative images presented here, if the court had realized that deportations to torture could hardly ever function effectively as an essential Canadian security strategy, and if the court had given credence to the alternative 'third way' component of between deportations to torture and complete freedom for the prospective deportees, it would have been much easier for it to argue and find in favour of an absolute bar on such deportations under Canadian law.

\section{The image of torture (and deportation to torture) in the decision}

This section, will attempt to tease out and analyse the image of torture (and deportation to torture) that is preferred and developed in the Suresh decision as well as the alternative image of that same phenomenon that is thus displaced, albeit in a subtle manner. It will also attempt to show how the preferred image worked to constrain the court's legal reasoning and decision, and enabled it to construct a particular contingent solution to the socio-legal problems posed by the appeal as the right answer - an answer that, in our considered view, falls far short of the protection needs of those refugees and other persons at risk who face deportation to torture.

The image of torture that is preferred and developed by the court in this decision is a pragmatically relativist one - that regards torture as mostly evil without completely prohibiting its condonation by Canada in certain 'exceptional circumstances' that arise out of a threat to Canada's national security. This much is evident from a careful analysis of the court's reasoning. The court started out by expressing quite strongly its firm conviction that torture, horrific a practice as it is, ought to be, and is indeed, rejected in the absolute sense in Canada. For instance, the court felt able to state that:

It can be confidently stated that Canadians do not accept torture as fair or compatible with justice. Torture finds no condonation in our Criminal Code; indeed the Code prohibits it. The Canadian people, speaking through their elected representatives, have rejected all forms of state-sanctioned torture. ${ }^{32}$

\footnotetext{
32 Suresh, n. I above at para. 50. Emphasis in the original. The condemnation of torture has been framed in the following terms by another court:

The crack of whip, the clamp of the thumb screw, the crush of the iron maiden, and, in these more efficient modern times, the shocks of the electric cattle prod are forms of torture that the
} 
What is more, the court also found that international law similarly prescribes an absolute bar on both torture and deportation to torture, and agreed that this attitude ought to inform their interpretation of Section 7 of the Charter. In the court's words:

We conclude that the better view is that international law rejects deportations to torture, even where national security interests are at stake. This is the norm which best informs the content of the principles of fundamental justice under s. 7 of the Charter. ${ }^{33}$

Somehow, however, the court ends up condoning in effect the likely torture of a refugee who is deported to torture by Canada in an exceptional case. According to the court:

. . barring extraordinary circumstances, deportation to torture will generally violate the principles of fundamental justice protected by $\mathrm{s.}$ of the Charter. ${ }^{34}$

international order will not tolerate. To subject a person to such horrors is to commit one of the most egregious violations of the personal security and dignity of human beings.

See Siderman de Blake v. Republic of Argentina, 965 F.2d 699, at 717 (9th Cir. 1992). Similarly, in Filartiga v. Pena-Irala, 630 F.2d 876 (2d Cir. 1980) at 890, the Second Circuit court held that:

Among the rights universally proclaimed by nations . . . is the right to be free of physical torture. Indeed, for purposes of civil liability, the torturer has become like the pirate and slave trader before him hostis humani generis, an enemy of all mankind. Our holding today . . . is a small but important step in the fulfillment of the ageless dream to free all people from brutal violence.

Several international instruments outlaw the practice of torture. For example, see Universal Declaration of Human Rights, G.A. Res. 217, UN GAOR, 3d Sess., pt. 1, at 71, UN Doc. A/810 (1948), [hereinafter UDHR]; International Covenant on Civil and Political Rights, (1966) 999 UNTS 171, UN Doc. A/6316 (1966) (entered into force March 23, 1976), Art. 7, [hereinafter ICCPR]; and the Torture Convention, above n. 17, Arts 2 and 3 especially.

For scholarly contributions in this regard, see P. v. W. Magee, 'The United Nations Convention Against Torture and Other Cruel, Inhuman or Degrading Treatment or Punishment: The Bush Administration's Stance on Torture' (1991-92) 25 George Washington Journal of International Law and Economics 807; Y. Gery, 'The Torture Victim Protection Act: Raising Issues of Legitimacy' (1993) 26 George Washington Joumal of International Law and Economics, 597 at 608; P. Burns \& O. Okafor, 'The United Nations Convention Against Torture and other Cruel, Inhuman or Degrading Treatment or Punishment or How it is still better to Light A candle than to Curse the darkness' (1998) 9:2 Otago Law Review 399 at 405 (the authors observed that: 'The convention absolutely prohibits torture and makes it punishable as a grave criminal offence. In addition, torture may not be justified on grounds of any exceptional circumstances whatsoever'); J. Horowitz, 'Genocide, War Crimes, and Crimes Against Humanity: Regina v. Bartle and the Commissioner of Police for the Metropolis and Others Ex Parte Pinochet: Universal Jurisdiction and Sovereign Immunity for Jus Cogens Violations' (1999) 23 Fordham International Journal 489 at 509 ; K.B. Rosati, "The United Nations Convention Against Torture: A Viable Alternative for Asylum Seekers' (1997) 74:45 INTERREL 1773 at 1783; K.B. Rosat, 'The United Nations Convention against Torture: A Detailed Examination of the Convention as an Alternative for Asylum seekers' (1997) 97-12 Immigr. Briefings 1 at 4; A. Boulesbaa, 'The Nature of the Obligations Incurred by States Under Article 2 of the UN Convention Against Torture' (1990) 12 Human Rights Quarterly 53 at 83; P. Burns, 'The United Nations Committee Against Torture And Its Role in Refugee Protection' (2001) 15 Georgetown Immigration Law Journal 403 at 406; and B. Gorlick, "The Convention and The Convention against Torture: A Complementary Protection Regime for Refugees' (1999) $11: 3$ IJRL 479 at 486 .

33 Ibid. at para. 75.

34 Ibid, at para. 76. Emphasis added. 
This turn, on the part of the court, from an absolute condemnation of torture to a relativist condoning of the practice, albeit in exceptional cases only, is highly significant given the court's explicit recognition in the decision that by deporting a refugee to torture, Canada actively facilitates and condones the torture of that refugee. In this sense the court was well aware that Canada was as responsible as any other country for any act(s) of torture that the deported refugee faced. According to the court:

We therefore disagree with the Court of Appeal's suggestion that, in expelling a refugee to a risk of torture, Canada acts only as an involuntary intermediary. Without Canada's action, there would be no risk of torture. Accordingly, we cannot pretend that Canada is merely a passive participant. ${ }^{35}$

Thus, it is fair to suggest that the preferred image of torture, and deportation to torture, in the decision is a pragmatically relativist one - a relativism towards torture that is based on the desire to secure Canada from threats to its security. It is a form of human rights relativism that may usefully be styled security relativism (in order to isolate it conceptually from classic cultural relativism). This form of relativism would suggest that a refugee's conduct can present such a risk to Canada's national security that Canadians, and Canadian courts, would not and should not in conscience be shocked by her or his deportation to a place where $s /$ he is likely to be tortured. Put differently, if the court recognizes, as it does, that deporting a refugee to torture directly implicates Canada in the act of torture itself, then in the 'exceptional cases' in which such a refugee is deported to torture, Canada's actions cannot but be viewed as suggesting that the person's plans or actions that threaten Canadian national security are so bad, and the person is therefore so bad herself, that Canada would facilitate her torture.

As justifiable as this kind of argument seems at first glance, it is seriously flawed nevertheless. It is similar to the seductive argument that is too often made in some quarters that Canadians suspected or convicted of committing serious crimes ought to be denied certain human rights protections, and/or treated less humanely in prison, on the basis that they are monsters. If the majority of Canadians have consistently rejected that argument as flawed, the argument that Canada ought to condone the deportation of a refugee to torture because of that person's criminal behaviour cannot pass muster either. It would be different, of course, if a refugee is deported in circumstances in which the risk of torture that $\mathrm{s} / \mathrm{he}$ faces is very low, and does not pass the litmus test of measuring up to a substantial risk. It is, however,

${ }^{35}$ Suresh, at para. 55. Emphasis supplied. 
disturbing that the court's decision leaves the door open to deportation in exceptional cases even when the refugee faces a high risk of torture. This is evident from the court's adoption of the balancing approach. In the court's reasoning, the risk of torture must be balanced against the security risk posed to Canadian national security. The implication then is that the higher the security risk to Canada the more likely it becomes that deportation to even certain torture would be viewed as justifiable. In this way did the court suggest that a substantial risk of torture upon deportation can be balanced away by the risk that the refugee presumably poses to Canadian national security.

Subtly displaced by the court's instrumentally-driven preferred image of torture (and deportation to torture) as risks that could be balanced away, is the alternative image of torture as wholly unacceptable one that cannot be balanced away in this sense. ${ }^{36}$ As the court acknowledges, this is the current position under international human rights law. ${ }^{37}$ It is now well accepted, as the court noted, that international human rights law absolutely prohibits torture or deportations to torture. Article 3 of the Torture Convention is explicit on this point. As the Committee Against Torture has itself made clear:

... the Act corresponds with article 3 of the Convention against Torture and states that an alien, who has been refused entry or who shall be expelled, may never be sent to a country where there is firm reason to believe that he or she would be in danger of suffering capital or corporal punishment or of being subjected to torture, nor to a country where he is not protected from being sent to a country where he would be in danger. ${ }^{38}$

It was in light of this international legal position that in Tahir Hussain Khan v. Canada, ${ }^{39}$ the Committee Against Torture (CAT) restrained Canada from returning Khan to Pakistan where he faced a substantial risk of torture. Khan was a member of Baltistan Student Federation, a political movement that is seeking self-determination for Kashmir. The CAT was satisfied that there existed substantial grounds for believing that he would be subjected to torture should he be returned to Pakistan. ${ }^{40}$ In Tapia Paez v. Sweden, ${ }^{41}$ a Peruvian national was refused convention refugee status in Sweden under the exclusion clause of

\footnotetext{
36 Apart from the Torture Convention, which prohibits torture unconditionally (particularly in its Articles 2 and 3), it is noteworthy that the International Covenant on Civil and Political Rights omits torture (which is prohibited by its Article 7) from the list of derogable human rights listed in its Article 4(2). See the International Covenant on Civil and Political Rights (ICCPR), above n. 32.

Ibid.

38 Pauline Muzonzo Paku Kisoki v. Sweden, Communication No. 41/1996.

39 Tahir Hussain Khan v. Canada - Communication No. 15/1994.

40 Ibid.

41 Communication No. 39/1996.
} 
Article $1 \mathrm{~F}$ of 1951 Convention on the ground that 'he had been armed and engaged in crimes during his political activities in Peru' ${ }^{42}$ His application not to be returned to Peru where he faces torture was granted by CAT. The CAT was of the opinion that regardless of the nature of his activities while in Peru, he came under the protection of Article 3 of Torture Convention and that the nature of his past conduct was not a relevant consideration under Article $3 .^{43}$ Also, in Avedes Hamayak Korban o. Sweden, ${ }^{44}$ an Iraqi citizen had sought asylum in Sweden. He was formerly a resident of Kuwait where he had sought refuge because of his opposition to Iraqi government. As a result of his nationality, he was imprisoned three times in Kuwait, tortured, and eventually deported to Iraq on 22 September $1991 .^{45}$ On arrival in Iraq, he was interrogated and later released on the condition that he would report daily to a government representative. Subsequently, he managed to escape to Jordan with his family. Though his wife was a Jordanian national, the Jordanian authorities refused him a residence permit. In 1993, he visited Iraq to see his dying mother. On this second visit, he was again arrested and detained for 14 days. He was later released on the condition that he would report daily to a government official in his neighbourhood. He later left Iraq when he learnt that his safety was at risk there. He travelled back to Jordan and stayed there for some time without a residence permit. He subsequently travelled on to Sweden where his son (who deserted from the Iraqi army) resided. The Swedish Immigration Board rejected his application for asylum on 26 September 1994. His deportation from Sweden was later ordered. ${ }^{46}$ At the CAT, the applicant contended that his return to Iraq would contravene Article 3 of the Torture Convention. In his view, he would likely face torture upon return to Iraq. He further contended that, since he was not a holder of Jordanian residence permit, it was unsafe for him to return there, as he faced the risk of being returned to Iraq from Jordan. ${ }^{47}$ He supported his application with some letters written by UNHCR to the Swedish Immigration Board explaining the fact that persons married to Jordanian women were not given preferential treatment in Jordan in the grant of residence permits. He also tendered another letter from the UNHCR showing that Iraqis returned from Sweden were routinely denied entry into Jordan. ${ }^{48}$ In its decision, the CAT held that the existence of a situation of serious human rights violations in Iraq coupled with the applicant's history of detention in

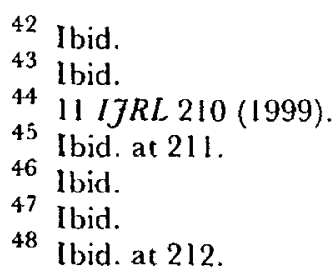


that country represented substantial grounds to believe that he would be in danger of being tortured on return to Iraq ${ }^{49}$ The Committee then recommended that Sweden refrain from returning the applicant to Jordan because of the risk he faced of being returned to Iraq from there. ${ }^{50}$

In the same manner, as the European Court of Human Rights stated quite clearly:

Article $3[E G H R]$ enshrines one of the most fundamental values of democratic society ... The court is well aware of the immense difficulties faced by states in modern times in protecting their communities from terrorist violence. However, even in these circumstances, the convention prohibits in absolute terms, torture or inhuman or degrading treatment or punishment irrespective of the victim's conduct ... Article 3 makes no provision for exceptions and no derogation from it is permissible ... even in the event of a public emergency threatening the life of the nation ... When substantial grounds have been shown for believing that an individual would face a risk of being subjected to treatment contrary to Article 3 if removed to another state, the responsibility of the contracting state to safeguard him or her against such treatment is engaged in the event of the expulsion... In these circumstances, the activities of the individual in question, however undesirable or dangerous cannot be a material consideration. The protection afforded by Article 3 is thus wider than that provided by Article 32 and 33 of the UN 1951 Convention on the Status of Refugees. ${ }^{51}$

What is more, the supreme court of at least one country has adopted a similar position. ${ }^{52}$

Similar views have been expressed by Peter Burns, the Canadian academic who is the current Chair of the CAT. In his view:

The combined effects of Articles 1, 3 and 22 [of the Torture Convention] enables individuals to complain directly to the committee that if, having failed to obtain refugee status, they are sent to or returned to a particular state where there are substantial grounds to believe that they would be in danger of being subjected to torture, then for a state to expel or return them would breach the Torture Convention... If they are successful in this claim then even if they are terrorists or criminals, they are entitled to the protection of the Torture Convention. Article 3 is non-derogable and cannot be diminished by a state party that may be influenced by matters of state security, international comity or even domestic politics. ${ }^{53}$

Thus, there is no alchemy, no natural law logic, that directs in favour of the Supreme Court of Canada's preferred image of a substantial risk of torture as a thing that can at a point be balanced away by a national

49 Ibid. at 216 .

50 Ibid.

51 See Chahal v. United Kingdom, Eur. Ct. H.R., $22441 / 93$ (1996).

52 See Hat'm Abu Zayda v. State of Israel (1999) 38 I.L.M. 1471.

53 See P. Burns, above n. 32 at 406 . Emphasis added. 
security risk. There is no non-contingent algebra in favour of the court's position. The court's logic was, therefore, obviously contingent, at least in this one respect. What the court did was to make a choice among competing images of torture and deportation to torture. It was partly this strategic choice that enabled the court to construct its specific solutions to the difficult socio-legal problems that were posed to it as the right answers. Without viewing torture and deportation to torture as things that could be balanced away, without adopting its balancing paradigm at all, the court would probably not have been able to construct a plausible argument for the legality and legitimacy of a deportation to torture, no matter how extraordinary the specific circumstances. In this connection, it would be instructive to ponder upon this question: would the court have resorted as easily to the balancing paradigm had the substantial risk posed to Mr Suresh by a possible deportation been his death in a genocidal campaign?

\section{The image of international normative authority in the decision}

This section will attempt to tease out and analyse the image of international normative authority that is preferred and developed in the Suresh decision as well as the alternative image of that same construct that is thus displaced. As in the last section, this article will also attempt to show how the preferred image worked to constrain the court's legal reasoning and decision in an unsatisfactory direction and enabled it to construct a particular contingent solution to the socio-legal problems posed by the appeal as the right answer. Here the purpose is not necessarily to show that one conception of international normative authority is always better than the other, as much as it is to show that the court's reliance on a particular notion of international normative authority was as a result of conscious (though subtle) normative choice on its part, a choice that in turn constrained its conclusions. Credible alternatives were definitely available to the court.

The image of international normative authority (more particularly the image of the authority exerted within Canada by international human rights norms) that was preferred by the court, is of the same relatively weak ilk as those that most Canadian courts have generally subscribed to over the years. ${ }^{54}$ Indeed, there can be very little doubt, if any at all, regarding the nature of the image of international normative authority preferred by the court. In this case, the court was at pains to make it clear that it does not subscribe to a strong image of the authority

54 For instance, see Baker v. Canada, (1999), 174 D.L.R. (4th) 193 at 230 (para. 69). 
of international human rights norms over the domestic behaviour of the Canadian government. According to the court:

In so far as Canada is unable to deport a person where there are substantial grounds to believe he or she would be tortured on return [except in exceptional cases], this is not because Article 3 of the CAT directly constrains the actions of the Canadian government ... ${ }^{55}$

The court's preference was for a weak image of international normative authority that absolutely excluded the possibility that a treaty such as the Torture Convention could be viewed by a domestic court of law in Canada as formally binding on the Canadian government - in terms of directly constraining its domestic behaviour. In accordance with the practice of most courts in most countries, ${ }^{56}$ the court constructed international human rights norms as incapable of directly governing domestic governance unless and until such norms are expressly incorporated into the domestic legal order by national legislation. ${ }^{57}$ The court felt able to maintain this position despite the fact that the international human rights obligations in question, specified as they are in a treaty that Canada had ratified, were freely assumed by Canada. ${ }^{58}$

Correctly in our view, the court also developed and relied on an image of international human rights norms as prescriptions that, even in the absence of their formally binding quality, ought to exert some cultural influence on the reasoning of Canadian courts - as constructs that must inform the search for the meaning of the provisions of Canada's domestic (human rights) legislation. ${ }^{59}$ However, given the nature of its reasoning in the present case, it is apparent that the court's conception of the level of cultural influence that these norms may exert on Canadian courts is relatively weak and limiled as well. For instance,

55 See Suresh, n. I above at para. 78. Emphasis added.

56 H.M. Kindred et al., International Law Chiefly as Interpreted and Applied in Canada, 6th edn., (Canada: Emond Montgomery Publications Limited, 2000) at 167, 168 \& 233-245.

57 Suresh, n. 1 above at para. 60.

58 Ibid. at para. 66.

59 On the question of the cultural influence of international human rights norms within domestic social and legal orders, see M. Mutua, 'Book Review' (2001) 95 AJIL 255. In this regard, Professor Mutua has noted quite correctly that:

The true test for the effectiveness of human rights law is not at the vertical level - that is, where international institutions act on domestic legal orders - but rather in the assimilation and adoption of human rights norms by and within states. Seen from this perspective, human rights norms have had an almost miraculous impact on the psyches of states, cultures, and societies around the world (at 256).

For a book-length ethnographic study that reaches similar conclusions with respect to one regional human rights regime, see O.C. Okafor, Do International Human Righls Institutions Matter? The Influence of the ACHPR within Nigeria (forthcoming). In this connection, see also T. Risse, S. Ropp, and K. Sikkink, eds., The Power of Human Rights: Intemational Norms and Domestic Change (New York: Cambridge University Press, 1999). For different perspectives, see T. Evans, ed., Human Rights Fifty Years On: A Reappraisal (Manchester: Manchester University Press, 1998); P. Baehr, Human 
the court explicitly recognized the absolute nature of the Torture Convention's prohibition against deportations to torture, ${ }^{60}$ and yet felt able to hold that its interpretation of Canadian law must leave open the possibility of deportations to torture, albeit in exceptional cases. Here, there is clearly a disjuncture between the position adopted by Canadian law and the legal requirement of at least one international human rights norm. Quite obviously therefore, while significant and thus laudable in itself, the extent of the cultural influence exerted on the court's reasoning by international law, was relatively weak and limited. Were the court to have been influenced more strongly, were its image of the cultural influence of international norms much stronger, it could have adopted the same position as under the Torture Convention, that is, it could have upheld an absolute bar on deportations to torture.

Rather, the court chose to displace alternative, if significantly stron$\mathrm{ger}$, images of formal international normative authority. Displaced from the court's reasoning process was an alternative image of freely assumed treaty obligations as in some way formally binding on, and/or directly constraining of, domestic governments, even when not re-enacted by local legislation. Unpopular among most domestic courts as it admittedly is, this is no longer a revolutionary conception of international normative authority at all. Ordinarily, domestic law has accepted the dual applicability of EU legislation and the ECJ's status is unique. ${ }^{61}$ The court's of a number of countries have for long recognized the concept of self-executing treaties that often apply directly within their respective states. ${ }^{62}$ The Nigerian Court of Appeal has held, on one occasion at least, that the African Charter on Human and Peoples' Rights applied directly to constrain the behaviour of a contemporary military regime. ${ }^{63}$ Though later overruled in some respects by the Nigerian Supreme Court, ${ }^{64}$ this decision, as well as the other instances already canvassed, aptly illustrate the fact that this alternative conception is not so naïve or beyond the pale that it could not have been developed and relied on by Supreme Court of Canada in the Suresh case. As the Nigerian Court of Appeal must have recognized, the hiatus between the adoption of a treaty by a state and that state's ratification of the same treaty provides an opportunity for it to refrain from becoming bound by a treaty it does not intend to directly govern its activities. In

Rights: Universality in Practice (New York: St. Martin's Press, 1999); and J.S. Watson, Theory and Reality in the International Protection of Human Rights (Ardstey NY: Transnational Publishers, 1999).

60 Suresh, above n. 1, at para. 75.

61 For example, see A-M. Burley and W. Mattli, 'Europe Before the Court: A Political Theory of Legal Integration' (1993) 47 Inlernational Organizalion 41 at 42.

62 H.M. Kindred et al, above n. 55 at $241-245$.

63 Fawhinmi v Abacha 9 NWLR (pt.475) 710 at 758-759 (C.A.).

64 See Abacha Ë ors v. Fawehinmi 6 NWLR (pt.660) 228 (2000) (S.C.). 
this way is the state's sovereign autonomy preserved. There is then very little compelling policy reasons why such a more monist scheme should not be adopted. In the end, the court lost yet another opportunity to take the lead globally in this respect.

Displaced as well from the court's reasoning process was an alternative, stronger, way of imagining the cultural influence of international human rights norms on a court's reasoning process. Admittedly, as long as an international norm does not formally bind a domestic court, that court is strictly speaking well within its rights not to apply that norm or not to apply it fully. However, the fact remains that if a court agrees that such international norms should nevertheless exert a cultural influence on its interpretation of the relevant domestic laws, that court is faced with a number of alternative ways of conceptualising its receptiveness to these strictly non-binding norms. The alternatives range from complete receptiveness to a very low level of receptiveness. In the Suresh case, the court preferred something in between these two points on the spectrum of receptivity. It chose a level of receptiveness that is significantly high yet disturbingly incomplete. It chose to receive only in part the categorical and absolute prohibition of deportation to torture under international human rights norms - however large the part that it received was. There was a clear gap, a hiatus, on this point between the court's position and the international legal position. This disjuncture could only have been possible because the court preferred a limited, weaker, alternative image of the cultural authority of international human rights norms within domestic legal orders.

It was only by skilfully displacing these two stronger and alternative images of the formal and cultural authority of international human rights norms that the court could create the necessary conditions for it to reach its highly consequential conclusion that Canadian law could authorize or allow a deportation to torture in exceptional cases. Had it found that international human rights norms were formally binding on Canadian domestic institutions and thus constrained these institutions directly, or that it was otherwise informally obligated to receive completely the prohibition of deportations to torture under international human rights law, it would have been extremely difficult, if not impossible, for the court to come to the conclusion that it did.

\section{The image of state sovereignty in the decision}

This section will attempt to tease out and analyse the image of state sovereignty that is preferred in the Suresh decision as well as the alternative image of that same phenomenon that is thus displaced. As in the preceding sections of this article, we will show how the preferred image worked to constrain the court's legal reasoning and decision, and 
enabled it to construct a particular contingent and unsatisfactory solution to the socio-legal problems posed by the appeal as the right answer. The purpose is not necessarily to show that one conception of state sovereignty is better than the other, as much as it is to show that the court's reliance on a particular notion of state sovereignty was as a result of normative choice that in turn constrained its conclusions in a particular direction. Credible alternatives were available to the court. By implication then, if another credible conception of state sovereignty was also available for the court to choose from, then at least one other 'right answer' to the major questions posed to the court was both possible and viable.

The image of state sovereignty that the court preferred is entailed by, and discernible from, its subscription in the decision to a relatively weak conception of international normative authority within domestic legal orders, one that effectively subordinates international norms to local legislation. In this decision, the court toed a line that was very close to the same absolutist strong conception of state sovereignty that has in the past received much censure mainly (but not exclusively) from the vast majority of (mainly) western political leaders and institutions. ${ }^{65}$ While the court did not articulate explicitly its subscription to this specific conception of state sovereignty, its adoption of that position is easily discerned from its reasoning process. One passage from the court's judgment is particularly instructive. According to the court:

Our concern is not with Canada's international obligations qua obligations... international law ... [is not] controlling in itself. ${ }^{66}$

Clearly, in the court's view, despite the fact that Canada had freely assumed certain international legal obligations, these international norms did not and could not govern its responses to the questions posed to it. According to the court, these norms could only act as interpretive aids to be used to the extent the court wished. The court was not, in its view, obliged to apply these international human rights norms. Clearly, as well, the basis for this conclusion was the presumed autonomy (read sovereignty) of the Canadian legal order vis-a-vis the international legal order. This strong assertion of autonomy has of course always been based on the dualist rather than monist conception of the relationship between a domestic legal order and the international legal order. ${ }^{67}$ More importantly, the court viewed the Canadian legal

${ }^{65}$ For instance, Lloyd Axworthy (until recently Canada's Minister of Foreign Affairs) has argued against a strong notion of state sovereignty on many occasions. For instance, see L. Axworthy, 'Human Security' and Global Governance: Putting People First' (2001) 7 Global Governance 19.

66 Suresh, n. I above at para. 60.

67 See H. Kindred et al., International Law Chiefly as Interpreted and Applied in Canada, above n. 55 at 229-233. 
order as virtually shielded by the concept of state sovereignty from the direct governance of international norms. We do not necessarily disagree with the deployment of sovereignty as a conceptual shield against foreign or international control, but seek to render explicit the court's strong pro-sovereignty posture in the face of perceived national emergency in Canada.

Displaced from the courts reasoning therefore was an alternative weaker conception of state sovereignty, one that Canadian and other western governments have promoted for decades as the panacea for most of the human rights and economic problems of the weaker Third World states, one that allows much more room for the penetration of foreign and international legal, economic, political, and social norms and power into the domestic orders of states. ${ }^{68}$ Thus, in the view of the Canadian government, this weak conception of state sovereignty has always been a credible and viable alternative to the virtually absolute or strong image of state sovereignty. ${ }^{69}$ Many serious and respected scholars also prefer this alternative image of state sovereignty. ${ }^{70}$ As this is not a treatise on state sovereignty, ${ }^{71}$ there is no need go into more detail regarding the nature of these conceptions, but suffice it so say that given its historical popularity in mostly (but not exclusively) western government and academic circles, the existence and nature of this weak image of state sovereignty could not have been unknown to the court. As such, its preference in this situation, for the strong version of state sovereignty was clearly a conscious normative choice.

It was only by carefully and subtly displacing this weak conception of state sovereignty in favour of a much stronger alternative that the court could plausibly refuse to accept the complete authority of freely assumed international human rights norms regarding the prohibition of deportation to torture within Canada's domestic legal order, and reject the notion that this issue was governed directly by those international human rights norms. And once the court could make a plausible argument that it was not obliged or strictly required to follow the dictates of these international human rights, it created space for it to substitute its own different judgment as to the legality of such deporta-

\footnotetext{
68 For an example of this kind of advocacy, see L. Axworthy, above n. 65; and W.M. Reisman, 'Sovereignty and Human Rights in Contemporary International Law' (1990) 84:4 AJIL 866 at 869-874.

69 Ibid.

70 See W.M. Reisman, above n. 67

71 For more on this concept, this defining feature of the post-westphalian international system, see S. Barkin \& B. Cronin, "The State and the Nation: Changing Norms and the Rule of Sovereignty in International Relations' (1994) 48:1 International Organization 107; G. Harding, 'Statist Assumptions, Normative Individualism and New Forms of Personality: Evolving a Philosophy of International Law for the Twenty-First Century' (2001) I Non-State Actors and International Law 107 at 110 ; and W.M. Reisman, above n. 67.
} 
tions. Such a different judgment would not have been possible had it subscribed to the weak conception of state sovereignty, and thus allowed that its decision was in this case governed directly by international norms. In that event, it would have most likely been forced to find other than as it did.

\section{The image of the institutional culture of the Canadian immigration bureaucracy in the decision}

This section will attempt to tease out and analyse the image of the institutional culture of the Canadian immigration bureaucracy (as represented primarily by the Department of Citizenship and Immigration or $\mathrm{CIC}^{72}$ ) that was impliedly developed, preferred and relied on (directly or indirectly) in the Suresh decision.

Implied strongly all through the court's judgment is a relatively benign image of CIC's institutional culture as primarily objective rather than basically biased in favour of the exclusion of prospective immigrants and refugees from Canada. That this was the dominant image of that institutional culture that operated within and helped to govern the court's reasoning process is evident from the nature of the court's conclusions and the structure of its logic. For instance, the court felt able to hold that the crucial 'threshold finding' of whether a refugee or other person would face a substantial risk of torture if deported to the state(s) to which they are deportable was the Minister's (read CIC's) to make, and that such decisions, once made by the Minister, should enjoy the highest possible level of deference. In practice, the Minister's decision would be extremely difficult to overturn primarily because the court found that, after weighing all the relevant factors that must be considered in deciding the standard of review with regard to a particular administrative decision, the appropriate standard of review with regard to the Minister's decisions regarding the deportation of refugees or other persons at risk to torture, was that the decision must not be disturbed unless it is shown to be patently unreasonable. This is the standard of deference that allows the most possible discretion (short of absolutism) to the Minister. In such situations, the reviewing court cannot set the Minister's decision aside even 'if it would have weighed the factors differently and arrived at a different conclusion'. ${ }^{73}$ The

\footnotetext{
72 Authors' note, we regard the Minister of Citizenship and Immigration (i.e. the Minister) as an integral part of $\mathrm{CIC}$ (that is, the Department of Citizenship and Immigration). In coming to her or his decisions, the Minister, who is an elected politician, more often than not relies heavily on the advice of the career civil servants employed by that department.

${ }^{3}$ Suresh, above n. 1 at para. 38.
} 
rationale that was offered by the Supreme Court for allowing such a high degree of deference to the Minister's decision in such cases was that the issues to be considered and factors to be weighed (by the Minister), such as the human rights record of the home state and the personal risk to the person to be deported, were "largely outside the realm of expertise of reviewing courts and possess a negligible legal dimension' ${ }^{74}$ Acknowledging that the court came to this conclusion after a thoughtful consideration of the issue of the 'appropriate standard of deference', it would seem that given the extremely severe repercussions for a person at risk, of a mistaken, negligent or wrong decision (usually death, or torture), the court's preparedness to allow such an extremely high level of virtually non-reviewable discretion to the Minister must have been premised on a much more benign image of CIC than many other judges and scholars have been prepared to allow. ${ }^{75}$ Since there is no suggestion of bad faith on the part of the court, it only makes sense to conclude that the court felt able to allow such an extremely high level of discretion to the Minister (CIC in effect) in relation to such a serious highly consequential matter, because the court expected (or preferred to expect) that, in reaching such decisions, the CIC would mostly behave and act in an objective, unbiased, way - thus reducing to the barest minimum the risk of mistaken or negligent deportations to torture. The court must have imagined that it was allowing such great powers to a CIC that is not systemically biased, one that is not characterized by an institutional culture that is biased in favour of exclusivist or restrictive immigration practices. Otherwise, the risk of a mistaken or negligent deportation would be too great to ignore. Surely, mindful as the court was of its formal duty to consider the factors that determine the nature of the standard of review, the court would not have been unmindful, at least informally, of the question of the workability in practice of the judicial review scheme that it was crafting, a scheme that was, after all, broadly designed to prevent the deportation of a refugee who faces a substantial risk of torture. Thus, the proper and just administration of the court's scheme cannot but be significantly tied to the existence of a CIC that is mostly unbiased (in the systemic sense) - a CIC that does not view its primary mission as the securement of Canada's borders from a real or imagined deluge of migrants and refugees. Otherwise the scheme would fail in the sense that a biased CIC would tend to act in ways that would result in the deportation of too many people to torture on too many occasions. In this sense then, did a mostly benign image of CIC's institutional culture frame the court's conclusions here.

\footnotetext{
74 Ibid. para. 39.

75 See Baker v. Canada, above n. 54 at 228-229. See also Sharry Aiken and Sheena Scott, below n. 83 at 244 .
} 
While this benign view of CIC's dominant institutional culture would be much welcome were it in fact accurate, such an image is regrettably unrealistic for the most part. An alternative and perhaps more realistic image of CIC's institutional culture, which views it much less benignly, was displaced by the court's sub-textual subscription to a mostly benign image of that same phenomenon. It has now become quite clear to most observers of that agency that, as a number of Canadian judges and scholars have observed, CIC's dominant institutional culture has not, for the most part, been biased in favour of the facilitation of the entry or admission of foreigners to Canada (as opposed to being biased in favour of the restriction of the entry of these foreigners) ${ }^{76} \mathrm{It}$ is in fact, on the balance, biased in favour of the exclusion of refugees from Canada. A few instances of this kind of systemic bias will suffice to illustrate this point. First of all, it is well known that CIC (on behalf of Canada) usually recommends and implements the imposition of travel visa restrictions on the citizens of a country as soon as that country begins to produce a significant number of refugee claimants in Canada. ${ }^{77}$ Its clear intention in those cases was to keep out possible refugees from reaching Canada. As the Canadian Council of Refugees has noted:

There is a correlation between the imposition of the visa requirement by Canada and the kinds of human rights abuses that causes refugees to flee. The worse the human rights abuses, the more likely the country is to have a visa requirement imposed on it. When refugee claimants start arriving in Canada from a country without a visa requirement, the government generally puts a visa requirement on the country, whether or not the claimants are in fact refugees. An example of this occurred in 1997, when there was an increase in arrivals of Roma claimants from Czech Republic, leading to the reimposition of the visa requirement, despite the fact that there was ample evidence that Roma were suffering serious human rights abuses in the Czech Republic. Canada uses the visa requirement to stop persecuted people from finding protection in Canada. ${ }^{78}$

Secondly, it is also trite knowledge that CIC makes every effort to prevent the arrival in Canada of refugee claimants who attempt to

76 Sec Baker v. Canada, above n. 54, at 228-229. See also Sharryn Aiken and Sheena Scott n. 83 below at 244 . issue):

As Hathaway and Neve noted a few years ago (in agreement with media comments on the

Gypsies escaping persecution in the Czech Republic will now find it almost impossible to seek asylum in Canada because of a new visa requirement that went into effect today. (Canadian Press, October 8, 1997) quoted in Canadian Council for Refugees, 'Interdicting Refugees' May 1998, at 3.

See J.C. Hathaway and R.A. Neve, 'Fundamental Justice and the Deflection of Refugees from Canada' (1996) 34:2 Osgoode Hall Law Journal 214 at 223-224.

78 Ibid. at $23-24$. 
circumvent the visa requirement. As one Canadian newspaper noted a few years ago:

Canadian immigration officials are now daily boarding international flights arriving in Vancouver [and other major. Canadian airports] in an effort to catch people entering the country on false documents. The procedure has already resulted in fines to the airlines bringing them here. ${ }^{79}$

It is such activities that have prompted two important Canadian refugee law scholars to point out the unfortunate, even tragic, paradox entailed in the fact that:

Although Canada is home to only about one-half of one percent of the world's refugees, it [CIC included] apparently sees no inconsistency between active participation in a program of deflection and its vaunted commitment to international burden sharing. ${ }^{80}$

Again, in Baker $v$ Canada, ${ }^{81}$ the Supreme Court of Canada noticed the blatantly expressed bias (at least on the part of one officer) in favour of restrictive immigration practices that was exhibited by the relevant CIC immigration officer. In that case, the notes of the officer who examined Ms. Baker in respect of her application for permanent residence in Canada on humanitarian and compassionate $(\mathrm{H} \& \mathrm{C})$ grounds clearly indicated a manifest exclusionary bias, and manifest disregard for the plight of a person in need and who clearly deserved compassion. The note, which was in the nature of a recommendation to a superior officer, read as follows:

The PC is paranoid schizophrenic and on welfare. She has no qualifications other than as a domestic. She has FOUR CHILDREN IN JAMAICA AND ANOTHER FOUR BORN HERE. She will, of course, be a tremendous strain on our social welfare systems for (probably) the rest of her life. There are no H\& $\mathrm{C}$ factors other than her FOUR CANADIAN-BORN CHILDREN. Do we let her stay because of that? I am of the opinion that Canada can no longer afford this kind of generosity. ${ }^{82}$

While it is conceded that bias on the part of one CIC officer does not mean there is systemic bias, it is contended that such a systemic bias exists. Apart from the other instances already recounted in this connection, the broad reaction of CIC to the Supreme Court of Canada's highly liberal decision in the Baker case, setting aside the earlier decisions of CIC and the lower courts, is highly instructive for our present

\footnotetext{
79 See Vancouver Sun, February 18, 1997 as quoted in Canadian Council for Refugees, Interdicting Refugees, May 1998 at 3.

80 J.C. Hathaway \& R.A. Neve, 'Deflection of Refugees', n. 77 above at 219.

81 Baker v. Minister of Citizenship and Immigration, above n. 54 .

82 Ibid. at 228-229. Emphasis in the original.
} 
purposes. While Ms. Baker was eventually granted permanent residence in Canada, and while the lower federal courts have attempted to follow the Supreme Court of Canada's lead, CIC has, as an institution, been highly resistant to a broad-based concrete implementation of the legal position adopted by the court in the case. As Sharryn Aiken and Sheena Scott have observed:

Nevertheless, it is certainly evident that the federal court is attempting to respond to the implications of the S.C. decision. In contrast, the immigration bureaucracy [read $\mathrm{CIC}$ ] has resisted any direct engagement with the ruling. Nine months after the court's decision, the department has not integrated the ruling into operational guidelines and appears to be committed to restricting the scope of its application. An internal memorandum issued in September 1999 from Ontario region concerning the removal of persons with pending H \& C applications is indicative of the department's approach. The memorandum indicates that the removal officers should "exercise good judgement when prioritizing their removal workload" and that barring any exceptional circumstances where deferral may be justified pending $\mathrm{H} \& \mathrm{C}$ application, removal should "proceed in the normal manner." The memo fails to make any mention of the best interests of children as a relevant factor in the officer's exercise of "good judgement" nor is there any indication that the Baker ruling might have implications for the manner in which removal decisions are made. ${ }^{83}$

This is not to argue, of course, either that CIC as an institution, or individual CIC officers, are either totally incapable of objectivity or have for the most part deliberately acted in bad faith toward prospective refugees or immigrants within or without Canada. The point that has been made is that it is because this large bureaucracy has evidently (and somewhat understandably) conceived of itself primarily as gatekeepers of a Canada that they see as under siege by a deluge of prospective refugee and migrants, as the agency responsible for excluding those that Canada's immigration/refugee law would not admit to Canada, that its broadly dominant institutional culture has tended to assume a bias toward the restriction of entry rather than the facilitation of admission. While both tendencies are of course reflected in CIC's institutional culture, the restrictive tendency has tended to dominate.

By displacing sub-textually this much less benign and, in our view, much more realistic primary image of CIC's institutional culture, the court was able to embrace the more benign understanding of $\mathrm{CIC}$, thus rendering its decision to allow in effect an extremely high level of discretion to GIC in deciding that a person does or does not face a substantial risk of torture (and/or that s/he is or is not a danger to national security) much more convincing than it would have been had

83 Sharryn Aiken and Sheena Scott, 'Baker v Canada (Minister of Citizenship \& Immigration) and the Rights of Children' (2000) 15 Journal of Law E' Social Policy 211 at 244. 
the court formed or privileged an alternative and much less benign image of that institution's systemic culture. Given that one of the factors that guides the court's decisions regarding the standard of deference it deems appropriate is the purpose of the legislation (including in this case, a consideration of the extent of the risk faced by the prospective deportee), had the court relied on the less benign image of CIC's dominant institutional culture (had it as a result become more deeply cognizant of the likelihood that the balancing process through which CIC decides if it should deport a refugee to torture may too often and become seriously deflected by a systemic institutional culture that favours restrictions on the entry of foreigners to Canada), the court may not have been as convinced of the appropriateness of allowing the highest available level of discretion to the Minister (read CIC). Again, had the court not relied as much as it did on the more benign image of CIC's institutional culture, it may not have been as convinced of the appropriateness of allowing, as it did, the normative opening in favour of deportations to torture (in exceptional cases). For the court would have displayed more awareness of the ways in which the CIC's dominant institutional culture favouring a more restrictive or exclusionary approach to immigration/refugee decision making would eventually lead to the subversion in far too many concrete cases of the court's general normative prohibition against deportations to torture. In practice, since the CIC's finding that a person does not face a substantial risk of torture on deportation will be very difficult to overturn in the courts, by simply ensuring that it weighs all the correct factors, and then finding upon some grounds (however weak these may seem to a refugee advocate) that the prospective deportee does not face a substantial risk of torture upon return, the CIC can almost always cause the deportation of a person to torture, even in those cases where it is clear to most people that the person faces some risk of torture. After all, it may be argued, not every risk of torture can be described as substantial. In this case, CIC can act in good faith and yet be completely wrong. Its knowledge and understanding of the situations in the often very distant lands that it is called upon to comment on has not always been as inspiring of confidence as it should. Yet unless it is proven to have acted in bad faith or arbitrarily, or there is no evidence to support its finding, or it failed to consider the appropriate factors, the courts cannot overturn its finding. It is also not unlikely at all that, far too often, CIC's decision-making may be inflected by its broad institutional bias in favour of the exclusion of refugee and prospective refugee-claimants from Canada. In the past, it has been extremely difficult to meet the extremely high standard necessary to convince a Canadian court to overturn an immigration decision that is shielded by such a highly deferential standard of review as is now enjoyed by the Minister in 
respect of her or his decisions to deport a refugee who may face a risk of torture abroad. ${ }^{84}$ As (then Professor, now Judge) John Evans has observed, Canadian judges have always undisguisedly shown deference to specialist Administrative Tribunals [and institutions] charged with the responsibility of administrating a particular programme. ${ }^{85}$ While showing deference to the decision of the Minister (read CIC) should not entail surrendering the court's supervisory powers, ${ }^{86}$ in practice the patently unreasonable standard has in the past served as a virtually impenetrable shield. Given CIC's broadly dominant pro-exclusionary institutional bias, the current legal position is hardly reassuring from the point of view of many prospective deportees at risk of torture. Laudable as it ordinarily seems, it may continue to license the deportation of persons at risk of torture to the very places that they are at risk.

\section{The emergent Canadian non-refoulement regime - the theory and the practice}

The foregoing sections of this article, attempted to explicate the various subtle ways in which the court developed, deployed, and relied on otherwise contingent images of Canadian national security, torture and deportations to torture, international normative authority, state sovereignty, and the institutional culture of the Canadian immigration bureaucracy, and displaced alternative (and perhaps even more viable) images of these constructs and phenomena, thereby constraining its reasoning process in one particular unsatisfactory direction, and presenting its particular overarching conclusion as the right answer - an answer that, arguably falls short of the protection needs of refugees and other persons at risk.

The present section will have a slightly different focus. Relying on many of the insights presented in the previous sections of this article, as well as on the pre-existing literature, this section will attempt to articulate the outlines of Canada's emergent, post-Suresh case, non-refoulement regime - connecting its conceptual framework to credible projections as to its concrete, practical implications. The principal objective is to relate the conclusions reached by the court in that case to the concrete circumstances that might be affected and governed by its legal logic.

\footnotetext{
84 See D. Bagambirre, Canadian Immigration and Refugee Law (Canada: Canada Law Book Inc., 1996) at 257-259 and 262-263.

85 J.M. Evans et al., Administrative Law, 3rd edn. (Toronto: Edmond Montgomery Publications Limited, 1989) at 414 .

${ }_{86}$ See D. Dyzenhaus, 'The Politics of Deference: Judicial Review and Democracy' in M. Taggart, ed., The Province of Administrative Lave (Oxford, England: Hart Publishing, 1997) 279 at 286.
} 


\subsection{The principle of non-refoulement}

Professor Guy Goodwin-Gill has described the principle of nonrefoulement as a fundamental basis of international refugee law. ${ }^{87}$ This principle precludes a state from returning a person against her or his will where s/he would be persecuted or face the risk of persecution. ${ }^{88}$ The principle is now widely regarded as a norm of customary international law that binds all states whether or not they are parties to the Convention. ${ }^{89}$ It is enunciated in Article 33(1) of the 1951 Refugee Convention. This provision prohibits states from taking any measure(s) that would lead to the return of a refugee to the place where that refugee's life or freedom would be threatened. It is suggested that any measure at all that leads to this outcome will constitute a violation of the principle of non-refoulement. ${ }^{90}$ However, Article 33 of the Refugee Convention permits an exception to this prohibition in cases where a refugee clearly constitutes a danger to the security of the country of refuge or where the refugee has been convicted of a serious crime and constitutes a danger to the community of that country. ${ }^{91}$

This fundamental international refugee law norm has been incorporated into Canadian refugee law by Section 53(1) of the current Canadian Immigration Act of 1978 (the old Act), and Section 115 of the Canadian Immigration and Refugee Protection Act of 2001 that came into effect in July 2002 (the new Act). The Supreme Court of Canada recently acknowledged the fact of Article 33's incorporation into Canadian law in Pushpanathan $v$ The Minister of Citizenship and Immigration. ${ }^{92}$

\subsection{The pre-Suresh legal position}

Prior to the decision of the court in the Suresh case, the non-refoulement regime under Canadian refugee law seemed to tally somewhat closely with the position under Article 33 of the Refugee Convention. Construed in the narrow way in which it has been read by many courts as well as by the Canadian immigration bureaucracy, the Canadian law relating to non-refoulement was that while, in general, refugees could not be deported to places where they faced the risk of persecution, they could be so

\footnotetext{
87 See G. Goodwin-Gill, The Refugee in International Law 2nd edn. (Oxford: Clarendon Press, 1996) at 137. See also J.C. Hathaway, The Law of Refugee Stalus (Toronto: Butterworths, 1991) at $24-27$; and D. Bagambiire, above n. 84 at 286-287.

88 Amnesty International, 'Refugees: Human Rights Have No Borders' on line: http:// www.amnesty.org/ailib/intcam/refugee/recommend.htm at 4 (visited: 0l/02/2002).

89 See G. Goodwin-Gill, above n. 87 at 167 . See also J.C. Hathaway, n. 87 above at 26.

90 G. Goodwin-Gill, ibid, at 142 \& 143.

91 This is Article 32(2) and it is by no means clear that the same applies to Article 33(2).

92 [1998] I S.C.R. 982 at 999.
} 
deported when they either posed a serious threat to the national security of the state of refuge. In this narrow and literal view of the law, just as the plain text of Article 33 of the Refugee Convention did not categorically reject deportation to torture, on its face Section 53(1) of the old Act leaves the door open for Canada to deport those refugees and other persons in need of protection in respect of whom there are reasonable grounds to believe that they have committed certain serious crimes (such as terrorism and espionage) specified under sections 19(1)(e), $(\mathrm{f}),(\mathrm{g}),(\mathrm{j}),(\mathrm{k})$ or $(\mathrm{l})$ of the old Act, and against whom the Minister has issued a certificate to the effect that they constitute dangers to the security of Canada. Those who preferred this narrow view of the nonrefoulement regime in Canada were either minded to virtually ignore Article 3 of the Torture Convention and Section 7 of the Canadian Charter of Rights and Freedoms (the Charter), or preferred to construe those provisions in ways that strictly restricted their ambit and import in relation to Section 53(1) of the old Act.

It was this kind of restrictive interpretation that the Federal Court of Appeal of Canada preferred in its own (now overruled) decision in the Suresh case. ${ }^{93}$ That court had held that not only did the Refugee Convention not bar the deportations of refugees to torture (in cases in which they posed a serious security risk to Canada), the Torture Convention must be read as not intending to limit the freedom allowed to states to deport refugees to torture under the Refugee Convention, but as permitting such deportations. That court also held that while the deportation of a refugee to torture would violate Section 7 of the Charter, it would be saved by Section 1 of that same legislation. As such, prior to the Suresh decision, it seemed that the general legal position was that a person who the Minister had certified as a danger to the security of Canada and who fell into one or more of the serious criminality classes specified under Section 19 of the old Act, could be deported to the place where $\mathrm{s} / \mathrm{he}$ was deportable notwithstanding that it was clear to the Minister that s/he faced a serious risk of persecution in that place, such as a substantial risk of torture. This position was justified on the basis of residual freedom allowed to states under Article 33(2) of the Refugee Convention, and by the fact that such an action would not shock the conscience of Canadians to an extent that would render it impermissible under Section 7 of the Charter. After all, it was argued, the prospective deportee would be a threat to the security of the nation. It must be remembered that in the Suresh case, the relevant immigration officer and the Minister had explicitly noted that $\mathrm{Mr}$ Suresh would probably face a substantial risk of torture if deported to Sri Lanka, yet the Minister had still proceeded to make a deportation order against him. Undoubtedly

93 [2000] 2 F.C. 592 (QL) at 623 para. 28 and 625 para. 32. 
therefore, the Minister had felt that it was well within her legal rights to deport a refugee to a place where s/he faced a substantial risk of torture once that person is viewed on reasonable grounds to pose a risk to the security of Canada. Instructively, both the Federal Court (Trial Division) and the Federal Court of Appeal upheld this view of the nature of Canada's non-refoulement regime.

\subsection{The formal legal position post-Suresh}

If this was the nature of the pre-Suresh Canadian non-refoulement regime (at least as interpreted by the Court of Appeal) the formal legal position was altered, conceptually at least, by the Suresh decision. Clearly, post 11 January 2002 Suresh decision, the Minister can no longer, in general, feel authorized by law to order the deportation of a refugee or other person in need of protection to a place where the targeted person would face a substantial risk of torture even when she has certified that person as posing a danger to the security of Canada. Thus, Canadian refugee law has acknowledged in this general (but limited) way the categorical bar imposed on deportation to torture by the Torture Convention. Canadian refugee law has also rejected the notion that the ambit of the nonrefoulement exception under Article 33(2) of the Refugee Convention has been left largely unrestricted by the entry into force of the Torture Convention (with its absolute prohibition of torture and deportation to torture). Clearly, at least under Canadian law, Article 33(2) must now be construed as much more restrictive of the ability of states to deport refugees. No longer can most deportations to torture be justified by simple reference to that treaty provision. This cannot but be so given the absolute bar on deportation to torture under the Torture Convention, and given the fact that, as the court noted in Suresh, the Torture Convention affords this protection to everyone - a term that cannot but include refugees. ${ }^{94}$ And so, refugees and other persons at risk of torture are in general now virtually insulated from deportation to those places where they face a substantial risk of torture. However, those refugees and refugee claimants who do not face a substantial risk of torture in the place(s) to which they are deportable are still generally deportable to such places if they are found to be national security risks under the procedure that is impliedly mandated by Section 53(1)(b) of the old Act.

However, even at the formal legal level, the emergent Canadian nonrefoulement regime does not still absolutely prohibit deportation to torture, such phenomena are prohibited in general only. A refugee who faces a substantial risk of torture may still be deported to torture in those exceptional cases where her deportation would not offend either

94 See Suresh, n. 1 above at para. 71. 
Section 7 (the principles of fundamental justice) or 1 (general saving clause) of the Charter. While the court did not offer any concrete examples of the kinds of scenarios that would fit within this exceptional power to deport to torture, it is reasonably safe to suppose that only persons who pose the most serious of threats to Canada, and in respect of whom the Minister is of the opinion that only deportation can assure the security of the realm, would easily fit within this exceptional category.

Thus, at the conceptual and formal legal level, Section 53(1)(b) of the old Act is now limited in its application to just two broad groups of otherwise deportable refugees: persons who do not face a substantial risk of torture in the place to which they are deportable, and persons who although they face such a risk are still deportable because they pose so great a risk to Canadian national security that their deportations would, regardless of their possible torture upon expulsion, not offend either section 7 or 1 of the Charter. The net cast by this new section 53(1) (b) as modified by the decision in Suresh is still a relatively wide one.

\subsection{The probable concrete legal situation post-Suresh}

Given the extremely high level of deference that the courts have in practice shown to the decisions of the Minister in this connection, decisions that are shielded by so wide a standard of review as the patently unreasonable test. More particularly, three critical decisions that will affect the concrete workings of Canada's emergent nonrefoulement regime are each shielded quite strongly by this virtually insurmountable standard of review. These decisions are as follows:

(i) the Minister's threshold decision that a refugee or other person in need of protection would face a substantial risk of torture if returned to the place to which s/he is removable (the substantial risk decision).

(ii) the Minister's decision that a person is a danger to the security of Canada (the danger decision).

(iii) the Minister's decision that after balancing the threat posed by the prospective deportee to Canada's security against the risk s/he faces upon deportation to the place where she is deportable, she must order the deportation of that person to that place, on the basis that in the circumstances the person's deportation would not offend either Section 7 or 1 of the Charler (the final deportation decision).

The net effect of the shield that the court has allowed the Minister in these three cases is that in all too many instances, the Minister can make 
each of these decisions with relatively little reasonable apprehension of her decision being overturned by the courts. In the past, Canadian courts have overturned only an extremely tiny percentage of administrative immigration decisions that are shielded by such stringent standards of review. ${ }^{95}$

As such, in the vast majority of cases, in cases in which the extent of the risk of torture faced by the prospective deportees will not always be as clear as it was in the Suresh case, the Minister will still be as free to deport persons s/he views as threats to the security of Canada as s/he was before the Suresh decision, even in those cases when the prospective deportee may in fact face a substantial risk of torture. Even though such an action would ordinarily offend the logic of the Suresh decision, it would still be possible - even probable. After all, the Minister's decision in each of these cases is not legally required to be correct. The only stricture that it has to face is that it must have been judiciously reached - that is, that it not be patently unreasonable. Such borderline deportations to torture can happen in cases where the Minister concludes that while the prospective deportee may face some risk of torture, the level of risk that $\mathrm{s} / \mathrm{he}$ faces does not rise to the level of a substantial risk of torture so as to generally preclude her or his deportation. Such borderline deportations to torture can also occur when the Minister admits that the person faces a substantial risk of torture upon return but finds that the facts of the case lend themselves to the conclusion that her or his deportation is warranted when the risk to Canada's security is balanced against the substantial risk of torture posed to the person by the deportation. In this last case, the balancing may be under Section 7 of the Charter (principles of fundamental justice) or under Section 1 of the Charter (the general saving clause of that legislation). Given the restrictive institutional culture of the agency that guides the Minister's decisions in such situations - their tendency to be biased in favour of exclusivist and restrictive immigration practices - and given the post-September 11 rise in xenophobia within the polity, it is not unreasonable to imagine that, regardless of any substantial risk of torture, in more cases than not, the Minister will be minded to find ways of deporting those s/he views as serious threats to Canada's national security. Surely, an elected politician such as the Minister could not afford to be unmindful of the nature of the prevalent political climate in contemporary Canada. The chances of the Minister being affected by the political climate are much improved by the fact that her decisions are usually guided by the decisions made by CICdecisions that we have already characterized as too often influenced by systemic exclusionary bias.

95 See D. Bagambiire, n. 84 above at 237 and 258. 


\section{Conclusions}

Acknowledging all along the fact that the decision of the Supreme Court of Canada in the Suresh decision was, for the most part, laudable, what this article did was to articulate, document, and demonstrate two overarching and inter-related critiques of this decision. The first of the two broad arguments was that the conclusions reached by the court were not altogether unassailable given the contingency of the doctrinal and policy constructs on which they were premised. It was only through a sophisticated and largely unjustified process of displacement (of alternative and competing images of the relevant constructs) that the court was able to present these conclusions as the right answer to the difficult questions posed to it. In this way was the court's reasoning constrained in ways that are, on balance, unsatisfactory. After all, there is no alchemy - no algebra - that inexorably favours the positions adopted by the court. Even more ethically and legally credible alternatives were available to it. By ignoring those credible alternatives, the court stopped far short of constructing a non-refoulement regime that could ensure the protection of refugees and other persons at risk from being deported to places where they are likely to be tortured. The objection that this was not possible to do because the law cannot and should not speak in absolutes is, as we have shown, rather unconvincing because the law already does absolutely prohibit the deportation of Canadian born threats to national security - what is more, their deportation to torture. As has been shown, the formalist distinction between citizen and non-citizen on this score is hardly reassuring to those in fear of terrorism. Neither is it ethically or substantively coherent.

In addition, for a number of connected reasons (especially those related to the court's grant of an extremely high level of extremely hard-to-review discretion to the Minister, and the systemic exclusionary bias of the Canadian immigration bureaucracy), that regime is likely to be more or less ineffective in practice, in terms of actually being applied in ways that ensure that the vast majority of those persons at risk of torture are not deported to places where they face a substantial risk of torture.

While the Suresh decision is definitely laudable, at least for the most part, and while that decision will likely serve Mr Suresh himself well, refugees and other persons at risk, as well as refugee scholars, lawyers and activists, may most likely find in the coming months and years that the Suresh decision may not provide as much succour and relief as could be expected. Thus, even though the non-refoulement norm is being reconfigured in Canada (mostly for the better), in practical terms, the results are not likely to be satisfactory in the long run. 